\title{
Pengembangan Modul Mata Kuliah Statistika Pendidikan di Fakultas Keguruan dan Ilmu Pendidikan Universitas Batanghari Jambi
}

\author{
Diliza Afrila', Akhmad Faisal Hidayat ${ }^{2}$ \\ ${ }^{1,2}$ FKIP Universitas Batanghari Jambi, Program Studi Pendidikan Ekonomi \\ Correspondence email: diliza.afrila15@gmail.com
}

\begin{abstract}
This study aims to determine (1) the process of developing Statistics Education module modules at the Teaching and Education Faculty of Batanghari University Jambi, (2) The eligibility of the Education Statistics module at the Teaching and Education Faculty of Batanghari University Jambi based on the assessment of material experts and media experts , and (3) Eligibility for Educational Statistics modules in the Teaching and Education Faculty of Batanghari University Jambi based on student assessment. The research the researcher carried out included research and development methods by adapting the ADDIE development model. The data collection instrument that researchers use is a questionnaire, which aims to measure the feasibility of the media, both by material experts, media experts, and students as material for evaluating the product / learning media developed. The results of the study show that (1) The process of developing the Education Statistics module modules refers to the ADDIE development model, namely (a) Analysis, namely needs analysis, material analysis, and competency analysis, (b) Design (Design), i.e. gathering the object of design and preparation of assessment instruments, (c) Development, namely the creation of instructional media, material validation, material revision, media validation, and media revision, (d) Implementation, namely One to One, Small Group, and Field Test, and (e) Evaluation, which analyzes the assessment of material and media experts, analyzes the assessment of students, and the final product, (2) The feasibility of Education Statistics modules based on material and media expert assessments, namely (a) Expert assessment material before revision obtained an average of 4.01, so it is in the feasible category. Meanwhile, the material expert assessment after the revision obtained an average of 4.53, so that it was in the very feasible category, and (b) The media expert assessment before the revision obtained an average of 4.09, so that it was in the feasible category. Meanwhile, the assessment of media experts after the revision obtained an average of 4.53, so that it was in the very feasible category, and (3) The feasibility of the Education Statistics modules based on student assessment, namely (a) One to One gained an average of 4.49 with TCR 89, 78 so that it is in the good category, (b) Small Group obtains an average of 4.16 with TCR 83.24 so that it is in the good category, and (c) Field Test obtains an average of 4.44 with TCR 88,71 so it is in the good category.
\end{abstract}

Keywords: Development; Modules; Education Statistics

\section{PENDAHULUAN}

Pendidikan merupakan salah satu upaya meningkatkan kualitas Sumber Daya Manusia (SDM). SDM yang berkualitas sangat penting dalam melaksanakan pembangunan berkelanjutan, baik fisik maupun non fisik. Universitas Batanghari Jambi sebagai salah satu lembaga pendidikan formal jenjang Pendidikan Tinggi memiliki peranan penting dalam mengembangkan dan membina potensi yang dimiliki oleh mahasiswa. Oleh karena itu, dosen di Universitas Batanghari Jambi dituntut untuk memiliki kompetensi, baik kompetensi pedagogik, kompetensi kepribadian, kompetensi profesional maupun kompetensi sosial yang mampuni guna mewujudkan output Universitas Batanghari Jambi yang berkualitas, sehingga mampu menghadapi persaingan yang semakin kompleks terutama di Era Masyarakat Ekonomi Asean (MEA) saat ini. Salah satu upaya yang dilakukan oleh Universitas Batanghari Jambi untuk meningkatkan kualitas output adalah menerapkan kurikulum yang sesuai dengan kebutuhan pangsa kerja.

Dalam kurikulum yang diterapkan oleh setiap Program Studi di Fakultas Keguruan dan Ilmu Pendidikan Universitas Batanghari Jambi memuat salah satu mata kuliah, yaitu mata kuliah Statistika
Pendidikan. Mata kuliah Statistika Pendidikan ini wajib dikontrak oleh seluruh mahasiswa Program Studi Pendidikan Ekonomi, Program Studi Pendidikan Sejarah, Program Studi Pendidikan Bahasa Inggris, dan Program Studi Pendidikan Bahasa dan Sastra Indonesia.

Berdasarkan observasi awal yang tim peneliti lakukan diperoleh gambaran bahwa proses pembelajaran mata kuliah Statistika Pendidikan belum efektif dan efisien. Hal ini dikarenakan dosen pengampu mata kuliah Statistika Pendidikan hanya mengandalkan bahan ajar konvensional, yang instan, tinggal pakai, tinggal beli, tanpa adanya upaya untuk merencanakan, menyiapkan, dan menyusun bahan ajar sendiri. Bahan ajar konvensional yang digunakan oleh dosen pengampu mata kuliah Statistika Pendidikan mengakibatkan proses pembelajaran Statistika Pendidikan menjadi tidak menarik, tidak menyenangkan, membosankan, dan monoton. Padahal, mata kuliah Statistika Pendidikan merupakan salah satu mata kuliah yang sangat penting bagi mahasiswa dalam menyelesaikan tugas akhir (skripsi). Dimana, kebanyakan penelitian mahasiswa di Fakultas Keguruan dan Ilmu Pendidikan adalah penelitian kuantitatif. Apabila mahasiswa tidak memahami mata kuliah Statistika Pendidikan, maka ia 
akan mengalami kesulitan dalam melakukan pengolahan data.

Penelitian yang peneliti laksanakan ini bertujuan untuk mengetahui (1) Proses pengembangan modul mata kuliah Statistika Pendidikan di Fakultas Keguruan dan Ilmu Pendidikan Universitas Batanghari Jambi, (2) Kelayakan modul mata kuliah Statistika Pendidikan di Fakultas Keguruan dan Ilmu Pendidikan Universitas Batanghari Jambi berdasarkan penilaian ahli materi dan ahli media, dan (3) Kelayakan modul mata kuliah Statistika Pendidikan di Fakultas Keguruan dan Ilmu Pendidikan Universitas Batanghari Jambi berdasarkan penilaian mahasiswa.

\section{METODE}

Penelitian yang peneliti laksanakan ini termasuk metode penelitian dan pengembangan (Research and Development). Menurut Sugiyono (2011:297) "Metode penelitian dan pengembangan atau dalam bahasa Inggrisnya Research and Development adalah metode penelitian yang digunakan untuk menghasilkan produk tertentu, dan menguji keefektifan produk tersebut". Prosedur penelitian yang digunakan mengadaptasi model pengembangan ADDIE. Gafur (2012:38) mengemukakan bahwa model ADDIE terdiri dari 5 (lima) langkah, yaitu:

1. Analisis (Analysis)

Analisis dilakukan untuk menentukan kebutuhan belajar, apa yang akan diajarkan, dan kompetensi apa yang diharapkan dikuasai mahasiswa setelah belajar.

2. Desain (Design)

Setelah kebutuhan belajar diidentifikasi, langkah berikutnya adalah mendesain pembelajaran. Kegiatan yang dilakukan pada tahap desain meliputi merumuskan kompetensi (tujuan pembelajaran khusus), menentukan materi pembelajaran, strategi, media, evaluasi, dan sumber.

3. Pengembangan (Develop)

Langkah pengembangan berupa memproduksi atau membuat atau mewujudkan spesifikasi pembelajaran yang telah ditentukan pada tahap desain.

4. Implementasi (Implement)

Setelah paket pembelajaran dikembangkan pada tahap 3 (tiga), langkah berikutnya adalah memanfaatkan atau menggunakan paket pembelajaran tersebut dalam kegiatan pembelajaran. Kegiatan yang perlu dipersiapkan antara lain jadwal, penyiapan ruang kelas, alat dan media, menyiapkan mahasiswa secara fisik maupun mental.

5. Evaluasi (Evaluate)

Evaluasi disini meliputi internal dan external evaluation. Evaluasi internal (evaluasi formatif) dilaksanakan untuk mengetahui efektifitas dan kualitas pembelajaran. Hasil evaluasi internal digunakan sebagai umpan balik untuk mengadakan perbaikan. Evaluasi eksternal (evaluasi sumatif) dimaksudkan untuk mengetahui tingkat penguasaan mahasiswa terhadap kompetensi yang telah diajarkan.

Instrumen pengumpulan data yang peneliti gunakan adalah angket. Sugiyono (2011:142) mengemukakan bahwa "Kuesioner adalah teknik pengumpulan data yang dilakukan dengan cara memberi seperangkat pertanyaan atau pernyataan tertulis kepada responden untuk dijawabnya". Angket penelitian ini bertujuan untuk mengukur kelayakan media, baik oleh ahli materi, ahli media, dan mahasiswa sebagai bahan untuk mengevaluasi produk/media pembelajaran yang dikembangkan. Angket penelitian ini disusun berdasarkan skala Likert. Sugiyono (2011:93) mengemukakan bahwa "Skala Likert adalah skala yang digunakan untuk mengukur sikap, pendapat, dan persepsi seseorang atau sekelompok orang tentang fenomena sosial". Skala Likert yang digunakan pada penelitian ini terdiri atas 5 (lima) alternatif jawaban, yaitu Sangat Baik, Baik, Cukup, Tidak Baik, dan Sangat Tidak Baik. Data yang diperoleh dianalisis guna mengetahui penilaian dan pendapat tentang produk yang dihasilkan.

\section{HASIL DAN PEMBAHASAN \\ Proses Pengembangan Modul Mata Kuliah Statistika Pendidikan}

Prosedur yang peneliti gunakan dalam pengembangan modul mata kuliah Statistika Pendidikan merujuk pada model pengembangan ADDIE. Adapun langkah-langkah model pengembangan ADDIE adalah sebagai berikut:

\section{Analisis (Analysis)}

Analisis dilakukan untuk menentukan kebutuhan belajar, apa yang akan diajarkan, dan kompetensi apa yang diharapkan dikuasai mahasiswa setelah belajar. Uraian dari masing-masing tahap analisis ini adalah sebagai berikut:

\section{Analisis kebutuhan}

Analisis kebutuhan peneliti peroleh melalui kegiatan observasi. Berdasarkan observasi yang peneliti lakukan diperoleh informasi bahwa dosen pengampu mata kuliah Statistika Pendidikan dalam proses pembelajaran hanya menggunakan metode ceramah dengan memanfaatkan papan tulis sebagai media pembelajaran. Dengan kata lain, dosen pengampu mata kuliah Statistika Pendidikan belum ada yang menggunakan modul selama proses pembelajaran. Dengan demikian, pengembangan modul ini diharapkan dapat meningkatkan kualitas pembelajaran dan kemandirian belajar mahasiswa pada mata kuliah Statistika Pendidikan. 


\section{Analisis materi}

Analisis materi diperoleh melalui kegiatan diskusi yang peneliti laksanakan dengan dosen pengampu mata kuliah Statistika Pendidikan yang ada di Fakultas Keguruan dan Ilmu Pendidikan Universitas Batanghari Jambi. Peneliti melaksanakan diskusi sebanyak 1 (satu) kali, yaitu dengan dosen pengampu mata kuliah Statistika Pendidikan di Program Studi Pendidikan Ekonomi (Pratiwi Indah Sari, M.PdE), Program Studi Pendidikan Sejarah (Nur Agustiningsih, M.Pd), dan Program Studi Pendidikan Bahasa dan Sastra Indonesia (Ayu Yarmayani, M.Pd) pada tanggal 15 Maret 2019. Pelaksanaan diskusi membahas tentang materi yang disajikan pada mata kuliah Statistika Pendidikan di masing-masing Program Studi.

\section{Analisis kompetensi}

Setelah materi yang akan dijabarkan ke dalam modul ditentukan, maka peneliti merumuskan kompetensi penunjang materi mata kuliah Statistika Pendidikan.

\section{Desain (Design)}

Setelah kebutuhan belajar diidentifikasi, langkah berikutnya adalah sebagai berikut:

\section{Pengumpulan objek rancangan}

Langkah dalam pengumpulan objek rancangan adalah penyusunan materi pembelajaran dan latihan. Materi pembelajaran disusun secara runtut berdasarkan referensi yang telah ditentukan sebelumnya. Dimana, referensi yang peneliti gunakan adalah buku Statistik karangan Prof. Dr. H. Agus Irianto, dan buku Dasardasar Statistik Pendidikan karangan Dr. Rahayu Kariadinata, M.Pd dan Dr. Maman Abdurahman, M.Pd.

1) Penyusunan instrumen penilaian
Instrumen penilaian yang peneliti susun terdiri atas 3 (tiga), yaitu instrumen penilaian tentang kelayakan materi oleh ahli materi, instrumen penilaian tentang kelayakan media oleh ahli media, dan instrumen penilaian tentang kelayakan materi dan media oleh mahasiswa. Instrumen-instrumen penilaian tersebut peneliti susun dalam bentuk angket dengan 5 (lima) alternatif jawaban, yaitu Sangat Baik, Baik, Cukup, Tidak Baik, dan Sangat Tidak Baik.

\section{Pengembangan (Develop)}

Pembuatan media pembelajaran

Berdasarkan desain yang sudah dirancang, maka peneliti membuat modul mata kuliah Statistika Pendidikan.

\section{Validasi Materi}

Materi pembelajaran divalidasi oleh 1 (satu) orang ahli materi, yaitu Ibu Ayu Yarmayani, M.Pd (Dosen Statistika Pendidikan di Program Studi Pendidikan Bahasa dan Sastra Indonesia Fakultas Keguruan dan Ilmu Pendidikan Universitas Batanghari Jambi). Instrumen penilaian berbentuk angket yang disusun menggunakan skala likert dengan 5 (lima) alternatif jawaban, yaitu Sangat Baik, Baik, Cukup, Tidak Baik, dan Sangat Tidak Baik. Instrumen penilaian ahli materi ini terdiri atas 21 (dua puluh satu) item pernyataan, yaitu 11 (sebelas) item pernyataan tentang aspek kelayakan isi dan 10 (sepuluh) item pernyataan tentang aspek kelayakan penyajian.

Materi pembelajaran ini divalidasi oleh Ibu Ayu Yarmayani, M.Pd pada 02 Mei 2019. Adapun hasil penilaian ahli materi tergambar pada tabel sebagai berikut:

Tabel 1. Rekapitulasi Hasil Penilaian Ahli Materi

\begin{tabular}{|c|c|c|}
\hline No. & Pernyataan & Skor \\
\hline \multicolumn{3}{|c|}{ Aspek Kelayakan Isi } \\
\hline 1 . & Kelengkapan materi & 3 \\
\hline 2. & Keluasan materi & 3 \\
\hline 3. & Kedalaman materi & 3 \\
\hline 4. & Keakuratan konsep dan definisi & 4 \\
\hline 5. & Keakuratan contoh & 4 \\
\hline 6. & Keakuratan istilah & 5 \\
\hline 7. & Keakuratan notasi, simbol, dan ikon & 3 \\
\hline 8. & Keakuratan acuan pustaka & 5 \\
\hline 9. & Kemutakhiran pustaka & 5 \\
\hline 10. & Mendorong rasa ingin tahu & 4 \\
\hline 11. & Menciptakan kemampuan bertanya & 4 \\
\hline & Total Skor & 43 \\
\hline & Rata- Rata Skor & 3,91 \\
\hline & Kategori & Layak \\
\hline \multicolumn{3}{|c|}{ Aspek Kelayakan Penyajian } \\
\hline 12. & Konsistensi sistematika sajian dalam kegiatan belajar & 4 \\
\hline 13. & Keruntutan konsep & 4 \\
\hline 14. & Contoh-contoh soal dalam setiap kegiatan belajar & 4 \\
\hline
\end{tabular}


Diliza Afrila dan Akhmad Faisal Hidayat, Pengembangan Modul Mata Kuliah Statistika Pendidikan di Fakultas Keguruan dan Ilmu Pendidikan Universitas Batanghari Jambi

15. Soal latihan pada setiap akhir kegiatan belajar

16. Pengantar

17. Daftar Pustaka

18. Rangkuman

19. Keterlibatan peserta didik

20. Ketertautan antar kegiatan belajar/sub kegiatan belajar/alinea

21. Keutuhan makna dalam kegiatan belajar/sub kegiatan belajar/ alinea

Total Skor

Rata- Rata Skor

Kategori

Sumber: Pengolahan Data Primer, 2019

Penilaian dari validator ini peneliti jadikan sebagai dasar dalam merevisi materi pembelajaran. Setelah peneliti melakukan revisi terhadap materi pembelajaran, maka pada 10 Mei 2019 peneliti menemui
Ibu Ayu Yarmayani, M.Pd untuk menunjukkan revisi materi pembelajaran. Adapun hasil penilaian ahli materi setelah revisi tergambar pada tabel sebagai berikut:

Tabel 2. Rekapitulasi Hasil Penilaian Ahli Materi Setelah Revisi

\begin{tabular}{|c|c|c|}
\hline No. & 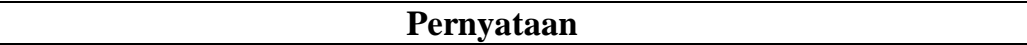 & Skor \\
\hline \multicolumn{3}{|c|}{ Aspek Kelayakan Isi } \\
\hline 1. & Kelengkapan materi & 4 \\
\hline 2. & Keluasan materi & 4 \\
\hline 3. & Kedalaman materi & 4 \\
\hline 4. & Keakuratan konsep dan definisi & 4 \\
\hline 5. & Keakuratan contoh & 5 \\
\hline 6. & Keakuratan istilah & 5 \\
\hline 7. & Keakuratan notasi, simbol, dan ikon & 4 \\
\hline 8. & Keakuratan acuan pustaka & 5 \\
\hline 9. & Kemutakhiran pustaka & 5 \\
\hline 10. & Mendorong rasa ingin tahu & 5 \\
\hline 11. & Menciptakan kemampuan bertanya & 5 \\
\hline & Total Skor & 50 \\
\hline & Rata- Rata Skor & 4,55 \\
\hline & Kategori & Sangat Layak \\
\hline \multicolumn{3}{|c|}{ Aspek Penyajian } \\
\hline 12. & Konsistensi sistematika sajian dalam kegiatan belajar & 4 \\
\hline 13. & Keruntutan konsep & 4 \\
\hline 14. & Contoh-contoh soal dalam setiap kegiatan belajar & 4 \\
\hline 15. & Soal latihan pada setiap akhir kegiatan belajar & 5 \\
\hline 16. & Pengantar 1 & 5 \\
\hline 17. & Daftar Pustaka & 5 \\
\hline 18. & Rangkuman & 5 \\
\hline 19. & Keterlibatan peserta didik & 5 \\
\hline 20. & Ketertautan antar kegiatan belajar/sub kegiatan belajar/ alinea & 4 \\
\hline \multirow[t]{4}{*}{21.} & Keutuhan makna dalam kegiatan belajar/sub kegiatan belajar/ alinea & 4 \\
\hline & Total Skor & 45 \\
\hline & Rata- Rata Skor & 4,5 \\
\hline & Kategori & Sangat Layak \\
\hline
\end{tabular}

Sumber: Pengolahan Data Primer, 2019

Revisi Materi

Adapun komentar dan saran perbaikan yang diberikan oleh Ibu Ayu Yarmayani, M.Pd pada tanggal 02 Mei 2019 adalah sebagai berikut:

Tabel 3. Komentar dan Saran Perbaikan Ahli Materi

\begin{tabular}{clc}
\hline No. & \multicolumn{1}{c}{ Komentar / Saran Perbaikan } & Keputusan \\
\hline 1. & Sajikan materi tentang skala pengukuran di dalam modul & Sudah direvisi \\
2. & Tingkat kesukaran soal latihan ditingkatkan dan jumlah soal latihan ditambah & Sudah direvisi \\
3. & Rumus-rumus yang disajikan di dalam modul dibuat menggunakan equation & Sudah direvisi \\
\hline
\end{tabular}




\section{Validasi Media}

Media pembelajaran divalidasi oleh 1 (satu) orang ahli media, yaitu Ibu Dr. Ade Rahima, M.Hum (Dosen Program Studi Pendidikan Bahasa dan Sastra Indonesia Fakultas Keguruan dan Ilmu Pendidikan Universitas Batanghari Jambi). Instrumen penilaian berbentuk angket yang disusun menggunakan skala likert dengan 5 (lima) alternatif jawaban, yaitu Sangat Baik, Baik, Cukup, Tidak Baik, dan Sangat Tidak Baik. Instrumen penilaian ahli media ini terdiri atas 28 (dua puluh delapan) item pernyataan, yaitu 18 item (delapan belas) item pernyataan tentang aspek kelayakan kegrafikaan dan 10 (sepuluh) item pernyataan tentang aspek kelayakan bahasa.

Media pembelajaran ini divalidasi oleh Ibu Dr. Ade Rahima, M.Hum pada 06 Mei 2019. Adapun hasil penilaian ahli media tergambar pada tabel sebagai berikut:

Tabel 4. Rekapitulasi Hasil Penilaian Ahli Media

\begin{tabular}{|c|c|c|}
\hline \multirow{2}{*}{\multicolumn{3}{|c|}{$\begin{array}{l}\text { No. } \\
\text { Aspek Kelayakan Kegrafikaan }\end{array}$}} \\
\hline & & \\
\hline 1. & $\begin{array}{l}\text { Penampilan unsur tata letak pada sampul muka, } \\
\text { belakang, dan punggung secara harmonis memiliki irama dan kesatuan serta konsisten }\end{array}$ & 3 \\
\hline 2. & Menampilkan pusat pandang yang baik & 3 \\
\hline 3. & Warna unsur tata letak harmonis dan memperjelas fungsi & 3 \\
\hline 4. & $\begin{array}{l}\text { Ukuran huruf judul modul lebih dominan dan proporsional dibandingkan ukuran modul } \\
\text { dan pengarang }\end{array}$ & 3 \\
\hline 5. & Warna judul modul kontras dengan warna latar belakang & 3 \\
\hline 6. & Tidak menggunakan banyak kombinasi jenis huruf & 5 \\
\hline 7. & Menggambarkan isi/materi ajar dan mengungkapkan karakter objek & 5 \\
\hline 8. & Penempatan unsur tata letak konsisten berdasarkan pola & 4 \\
\hline 9. & Pemisahan antar paragraf jelas & 5 \\
\hline 10. & Bidang cetak dan margin proporsional & 4 \\
\hline 11. & Spasi antar teks dan ilustrasi sesuai & 4 \\
\hline 12. & Judul kegiatan belajar, sub judul kegiatan belajar, dan angka halaman/folio & 5 \\
\hline 13. & Tidak menggunakan terlalu banyak jenis huruf & 5 \\
\hline 14. & Penggunaan variasi huruf (bold, italic, all capital, small capital) tidak berlebihan & 5 \\
\hline 15. & Spasi antar baris susunan teks normal & 5 \\
\hline 16. & Spasi antar huruf normal & 5 \\
\hline 17. & Jenjang atau hirarki judul-judul jelas, konsisten, dan proporsional & 4 \\
\hline 18. & Tanda pemotong kata & 4 \\
\hline & Total Skor & 75 \\
\hline & Rata-rata Skor & 4,17 \\
\hline & Kategori & Layak \\
\hline \multicolumn{3}{|c|}{ Aspek Kelayakan Bahasa } \\
\hline 19. & Ketepatan struktur kalimat & 4 \\
\hline 20. & Keefektifan kalimat & 4 \\
\hline 21. & Kebakuan istilah & 4 \\
\hline 22. & Pemahaman terhadap pesan atau informasi & 4 \\
\hline 23. & Kemampuan memotivasi peserta didik & 4 \\
\hline 24. & Kesesuaian dengan perkembangan intelektual peserta didik & 5 \\
\hline 25. & Ketepatan tata bahasa & 4 \\
\hline 26. & Ketepatan ejaan & 4 \\
\hline 27. & Konsistensi penggunaan istilah & 4 \\
\hline 28. & Konsistensi penggunaan simbol atau ikon & 3 \\
\hline & Total Skor & 40 \\
\hline & Rata-rata Skor & 4 \\
\hline & Kategori & Layak \\
\hline
\end{tabular}

Sumber: Pengolahan Data Primer, 2019

Penilaian dari validator ini peneliti jadikan sebagai dasar dalam merevisi media pembelajaran. Setelah peneliti melakukan revisi terhadap media pembelajaran, maka pada 22 Mei 2019 peneliti menemui
Ibu. Dr. Ade Rahima, M.Hum untuk menunjukkan media pembelajaran yang telah peneliti revisi. Adapun hasil penilaian ahli media setelah revisi tergambar pada tabel sebagai berikut: 
Diliza Afrila dan Akhmad Faisal Hidayat, Pengembangan Modul Mata Kuliah Statistika Pendidikan di Fakultas Keguruan dan Ilmu Pendidikan Universitas Batanghari Jambi

Tabel 5. Rekapitulasi Hasil Penilaian Ahli Media Setelah Revisi

\begin{tabular}{|c|c|c|}
\hline No. & Pernyataan & Skor \\
\hline \multicolumn{3}{|c|}{ Aspek Kelayakan Kegrafikaan } \\
\hline 1. & $\begin{array}{l}\text { Penampilan unsur tata letak pada sampul muka, belakang, dan punggung secara } \\
\text { harmonis memiliki irama dan kesatuan serta konsisten }\end{array}$ & 4 \\
\hline 2. & Menampilkan pusat pandang yang baik & 4 \\
\hline 3. & Warna unsur tata letak harmonis dan memperjelas fungsi & 4 \\
\hline $4 .$. & $\begin{array}{l}\text { Ukuran huruf judul modul lebih dominan dan proporsional dibandingkan ukuran } \\
\text { modul dan pengarang }\end{array}$ & 4 \\
\hline 5. & Warna judul modul kontras dengan warna latar Belakang & 4 \\
\hline 6. & Tidak menggunakan banyak kombinasi jenis huruf & 5 \\
\hline 7. & Menggambarkan isi/materi ajar dan mengungkapkan karakter objek & 5 \\
\hline 8. & Penempatan unsur tata letak konsisten berdasarkan pola & 4 \\
\hline 9. & Pemisahan antar paragraf jelas & 5 \\
\hline 10. & Bidang cetak dan margin proporsional & 4 \\
\hline 11. & Spasi antar teks dan ilustrasi sesuai & 4 \\
\hline 12. & Judul kegiatan belajar, sub judul kegiatan belajar, dan angka halaman/folio & 5 \\
\hline 13. & Tidak menggunakan terlalu banyak jenis huruf & 5 \\
\hline 14. & Penggunaan variasi huruf (bold, italic, all capital, small capital) tidak berlebihan & 5 \\
\hline 15. & Spasi antar baris susunan teks normal & 5 \\
\hline 16. & Spasi antar huruf normal & 5 \\
\hline 17. & Jenjang atau hirarki judul-judul jelas, konsisten, dan proporsional & 5 \\
\hline 18. & Tanda pemotong kata & 5 \\
\hline & Total Skor & 82 \\
\hline & Rata-rata Skor & 4,56 \\
\hline & Kategori & Sangat Layak \\
\hline \multicolumn{3}{|c|}{ Aspek Kelayakan Bahasa } \\
\hline 19. & Ketepatan struktur kalimat & 5 \\
\hline 20. & Keefektifan kalimat & 4 \\
\hline 21. & Kebakuan istilah & 5 \\
\hline 22. & Pemahaman terhadap pesan atau informasi & 4 \\
\hline 23. & Kemampuan memotivasi peserta didik & 5 \\
\hline 24. & Kesesuaian dengan perkembangan intelektual peserta didik & 5 \\
\hline 25. & Ketepatan tata bahasa & 4 \\
\hline 26. & Ketepatan ejaan & 4 \\
\hline 27. & Konsistensi penggunaan istilah & 5 \\
\hline 28. & Konsistensi penggunaan simbol atau ikon & 4 \\
\hline & Total Skor & 45 \\
\hline & Rata-rata Skor & 4,5 \\
\hline & Kategori & Sangat Layak \\
\hline
\end{tabular}

Sumber: Pengolahan Data Primer, 2019

Revisi Media

Adapun komentar dan saran perbaikan yang diberikan oleh Ibu Dr. Ade Rahima, M.Hum pada tanggal 06 Mei 2019 adalah sebagai berikut:

Tabel 6. Komentar dan Saran Perbaikan Ahli Media

\begin{tabular}{clc}
\hline No. & \multicolumn{1}{c}{ Komentar / Saran Perbaikan } & Keputusan \\
\hline 1. & Tampilan warna judul diperbaiki (warna judul ditampilkan lebih menonjol dari pada & Sudah direvisi \\
warna latar belakangnya) & Sudah direvisi \\
2. & Jarak spasi jangan terlalu sempit karena mahasiswa sulit membaca modul & Sudah direvisi \\
\hline
\end{tabular}

\section{Implementasi (Implement)}

Setelah materi dan media pembelajaran direvisi sesuai dengan komentar dan saran dari validator, maka penelitian ini peneliti lanjutkan pada tahap implementasi, yang terdiri atas langkah-langkah sebagai berikut:

\section{One to One}

Tahap One to One peneliti laksanakan pada 17 Juni 2019. Pada tahap ini, modul mata kuliah Statistika Pendidikan peneliti ujicobakan kepada 3 (tiga) orang mahasiswa. Sebelum pelaksanaan uji coba, peneliti menjelaskan tentang modul mata kuliah Statistika Pendidikan di depan kelas. Pada akhir pertemuan, 
peneliti memberikan instrumen penilaian yang berkaitan dengan penilaian mahasiswa tentang materi dan media pembelajaran (modul). Instrumen penilaian ini berbentuk angket yang disusun menggunakan skala likert dengan 5 (lima) alternatif jawaban, yaitu Sangat
Setuju, Setuju, Kurang Setuju, Tidak Setuju, dan Sangat Tidak Setuju. Instrumen penilaian mahasiswa ini terdiri atas 15 (lima belas) item pernyataan. Penilaian mahasiswa peserta One to One ini tergambar tabel di bawah ini:

Tabel 7. Rekapitulasi Hasil Penilaian Mahasiswa Peserta One to One

\begin{tabular}{|c|c|c|c|c|}
\hline No. & Pernyataan & Mean & TCR & Kategori \\
\hline 1. & $\begin{array}{l}\text { Saya dapat memahami materi yang disajikan dalam modul } \\
\text { dengan Mudah }\end{array}$ & 4.67 & 93.33 & Sangat Baik \\
\hline 2. & $\begin{array}{l}\text { Penyajian materi dalam modul ini dimulai dari yang mudah } \\
\text { ke sukar dan dari yang konkret ke abstrak }\end{array}$ & 4.33 & 86.67 & Baik \\
\hline 3. & $\begin{array}{l}\text { Materi yang disajikan dalam modul ini mendorong rasa } \\
\text { keingintahuan Saya }\end{array}$ & 4.33 & 86.67 & Baik \\
\hline 4. & $\begin{array}{l}\text { Penyajian materi dalam modul ini mendorong saya untuk } \\
\text { berdiskusi dengan teman-teman yang lain }\end{array}$ & 5.00 & 100.00 & Sangat Baik \\
\hline 5. & $\begin{array}{l}\text { Contoh soal yang terdapat dalam modul ini sudah sesuai } \\
\text { dengan Materi }\end{array}$ & 4.00 & 80.00 & Baik \\
\hline 6. & $\begin{array}{l}\text { Modul ini memuat soal-soal yang mendorong saya untuk } \\
\text { berpikir }\end{array}$ & 4.33 & 86.67 & Baik \\
\hline 7. & $\begin{array}{l}\text { Modul ini memuat tes formatif yang dapat menguji seberapa } \\
\text { jauh pemahaman saya tentang materi }\end{array}$ & 4.67 & 93.33 & Sangat Baik \\
\hline 8. & Kalimat digunakan dalam modul ini jelas dan mudah dipahami & 4.67 & 93.33 & Sangat Baik \\
\hline 9. & $\begin{array}{l}\text { Bahasa yang digunakan dalam modul ini sederhana dan } \\
\text { mudah dimengerti }\end{array}$ & 5.00 & 100.00 & Sangat Baik \\
\hline 10. & Huruf yang digunakan dalam modul ini mudah dibaca & 4.00 & 80.00 & Baik \\
\hline 11. & Tampilan modul ini menarik & 4.00 & 80.00 & Baik \\
\hline 12. & Modul ini bisa digunakan untuk belajar mandiri & 4.33 & 86.67 & Baik \\
\hline 13. & $\begin{array}{l}\text { Penggunaan modul ini membuat kegiatan belajar saya menjadi } \\
\text { terarah dan runtut }\end{array}$ & 5.00 & 100.00 & Sangat Baik \\
\hline 14. & Modul ini membuat saya senang belajar Statistika Pendidikan & 4.00 & 80.00 & Baik \\
\hline \multirow[t]{2}{*}{15.} & $\begin{array}{l}\text { Dengan menggunakan modul ini membuat belajar Statistika } \\
\text { Pendidikan tidak membosankan }\end{array}$ & 5.00 & 100.00 & Sangat Baik \\
\hline & Rata-rata & $\mathbf{4 , 4 9}$ & 89.78 & Baik \\
\hline
\end{tabular}

Sumber: Pengolahan Data Primer, 2019

Berdasarkan kriteria konversi diketahui bahwa penilaian mahasiswa peserta One to One tentang materi dan modul mata kuliah Statistika Pendidikan memperoleh rata-rata sebesar 4,49, sehingga berada pada kategori sangat layak. Selain itu, penilaian mahasiswa peserta One to One tentang materi dan modul mata kuliah Statistika Pendidikan memperoleh Tingkat Capaian Responden (TCR) sebesar 89,78, sehingga berada pada kategori baik.

\section{Small Group}

Tahap Small Group peneliti laksanakan pada 24 Juni 2019. Pada tahap ini, modul mata kuliah Statistika Pendidikan peneliti ujicobakan kepada 7 (tujuh) orang mahasiswa. Sebelum pelaksanaan uji coba, peneliti menjelaskan kepada mahasiswa tentang modul mata kuliah Statistika Pendidikan di depan kelas. Pada akhir pertemuan, peneliti memberikan instrumen penilaian yang berkaitan dengan penilaian mahasiswa tentang materi dan media pembelajaran (modul). Instrumen penilaian ini berbentuk angket yang disusun menggunakan skala likert dengan 5 (lima) alternatif jawaban, yaitu Sangat Setuju, Setuju, Kurang Setuju, Tidak Setuju, dan Sangat Tidak Setuju. Instrumen penilaian mahasiswa ini terdiri atas 15 (lima belas) item pernyataan. Penilaian mahasiswa peserta Small Group ini tergambar pada tabel di bawah ini: 
Diliza Afrila dan Akhmad Faisal Hidayat, Pengembangan Modul Mata Kuliah Statistika Pendidikan di Fakultas Keguruan dan Ilmu Pendidikan Universitas Batanghari Jambi

Tabel 8. Rekapitulasi Hasil Penilaian Mahasiswa Peserta Small Group

\begin{tabular}{|c|c|c|c|c|}
\hline No & Pernyataan & Mean & TCR & Kategori \\
\hline 1. & $\begin{array}{l}\text { Saya dapat memahami materi yang disajikan dalam modul } \\
\text { dengan mudah }\end{array}$ & 4.57 & 91.43 & Sangat Baik \\
\hline 2. & $\begin{array}{l}\text { Penyajian materi dalam modul ini dimulai dari yang mudah ke } \\
\text { sukar dan dari yang konkret ke abstrak }\end{array}$ & 4.00 & 80.00 & Baik \\
\hline 3. & $\begin{array}{l}\text { Materi yang disajikan dalam modul ini mendorong rasa } \\
\text { keingintahuan saya }\end{array}$ & 4.57 & 91.43 & Sangat Baik \\
\hline 4. & $\begin{array}{l}\text { Penyajian materi dalam modul ini mendorong saya untuk } \\
\text { berdiskusi dengan teman-teman yang lain }\end{array}$ & 4.29 & 85.71 & Baik \\
\hline 5. & $\begin{array}{l}\text { Contoh soal yang terdapat dalam modul ini sudah sesuai } \\
\text { dengan Materi }\end{array}$ & 4.00 & 80.00 & Baik \\
\hline 6. & $\begin{array}{l}\text { Modul ini memuat soal-soal yang mendorong saya untuk } \\
\text { berpikir }\end{array}$ & 4.29 & 85.71 & Baik \\
\hline 7. & $\begin{array}{l}\text { Modul ini memuat tes formatif yang dapat menguji seberapa } \\
\text { jauh pemahaman saya tentang materi }\end{array}$ & 4.43 & 88.57 & Baik \\
\hline 8. & $\begin{array}{l}\text { Kalimat dan paragraf yang digunakan dalam modul ini jelas dan } \\
\text { mudah dipahami }\end{array}$ & 4.14 & 82.86 & Baik \\
\hline 9. & $\begin{array}{l}\text { Bahasa yang digunakan dalam modul ini sederhana dan mudah } \\
\text { dimengerti }\end{array}$ & 4.00 & 80.00 & Baik \\
\hline 10. & Huruf yang digunakan dalam modul ini mudah dibaca & 4.00 & 80.00 & Baik \\
\hline 11. & Tampilan modul ini menarik & 4.14 & 82.86 & Baik \\
\hline 12. & Modul ini bisa digunakan untuk belajar mandiri & 4.29 & 85.71 & Baik \\
\hline 13. & $\begin{array}{l}\text { Penggunaan modul ini membuat kegiatan belajar saya menjadi } \\
\text { terarah dan runtut }\end{array}$ & 4.14 & 82.86 & Baik \\
\hline 14. & Modul ini membuat saya senang belajar Statistika Pendidikan & 3.71 & 74.29 & Cukup \\
\hline \multirow[t]{2}{*}{15.} & $\begin{array}{l}\text { Dengan menggunakan modul ini membuat belajar Statistika } \\
\text { Pendidikan tidak membosankan }\end{array}$ & 3.86 & 77.14 & Cukup \\
\hline & Rata-rata & 4.16 & 83.24 & Baik \\
\hline
\end{tabular}

Sumber: Pengolahan Data Primer, 2019

Berdasarkan kriteria konversi diketahui bahwa penilaian mahasiswa peserta Small Group tentang materi dan modul mata kuliah Statistika Pendidikan memperoleh rata-rata sebesar 4,16, sehingga berada pada kategori layak. Selain itu, penilaian mahasiswa peserta Small Group tentang materi dan modul mata kuliah Statistika Pendidikan memperoleh Tingkat Capaian Responden (TCR) sebesar 83,24, sehingga berada pada kategori baik.

\section{Field Test}

Tahap Field Test peneliti laksanakan pada 04 Juli 2019. Pada tahap ini, modul mata kuliah Statistika Pendidikan peneliti terapkan kepada 15 (lima belas) orang mahasiswa Program Studi Pendidikan Ekonomi Fakultas Keguruan dan Ilmu Pendidikan Universitas Batanghari Jambi. Pada akhir pertemuan, peneliti memberikan instrumen penilaian yang berkaitan dengan penilaian mahasiswa tentang materi dan media pembelajaran (modul). Instrumen penilaian ini berbentuk angket yang disusun menggunakan skala likert dengan 5 (lima) alternatif jawaban, yaitu Sangat Setuju, Setuju, Kurang Setuju, Tidak Setuju, dan Sangat Tidak Setuju. Instrumen penilaian mahasiswa ini terdiri atas 15 (lima belas) item pernyataan. Penilaian mahasiswa peserta Field Test ini tergambar pada tabel di bawah ini:

Tabel 9. Rekapitulasi Hasil Penilaian Mahasiswa Peserta Field Test

\begin{tabular}{|c|c|c|c|c|}
\hline No & Pernyataan & Mean & TCR & Kategori \\
\hline 1. & $\begin{array}{l}\text { Saya dapat memahami materi yang disajikan dalam modul } \\
\text { dengan mudah }\end{array}$ & 4.53 & 90.67 & Sangat Baik \\
\hline 2. & $\begin{array}{l}\text { Penyajian materi dalam modul ini dimulai dari yang mudah ke } \\
\text { sukar dan dari yang konkret ke abstrak }\end{array}$ & 4.53 & 90.67 & Sangat Baik \\
\hline 3. & $\begin{array}{l}\text { Materi yang disajikan dalam modul ini mendorong rasa } \\
\text { keingintahuan saya }\end{array}$ & 4.60 & 92.00 & Sangat Baik \\
\hline 4. & $\begin{array}{l}\text { Penyajian materi dalam modul ini mendorong saya untuk } \\
\text { berdiskusi dengan teman-teman yang lain }\end{array}$ & 4.47 & 89.33 & Baik \\
\hline 5. & $\begin{array}{l}\text { Contoh soal yang terdapat dalam modul ini sudah sesuai } \\
\text { dengan Materi }\end{array}$ & 4.27 & 85.33 & Baik \\
\hline 6. & $\begin{array}{l}\text { Modul ini memuat soal-soal yang mendorong saya untuk } \\
\text { berpikir }\end{array}$ & 4.33 & 86.67 & Baik \\
\hline
\end{tabular}


7. Modul ini memuat tes formatif yang dapat menguji seberapa jauh pemahaman saya tentang materi

\begin{tabular}{|c|c|c|}
\hline 4.60 & 92.00 & Sangat Baik \\
\hline 4.00 & 80.00 & Baik \\
\hline 4.53 & 90.67 & Sangat Baik \\
\hline 4.53 & 90.67 & Sangat Baik \\
\hline 4.53 & 90.67 & Sangat Baik \\
\hline 4.60 & 92.00 & Sangat Baik \\
\hline 4.53 & 90.67 & Sangat Baik \\
\hline 4.20 & 84.00 & Baik \\
\hline 4.27 & 85.33 & Baik \\
\hline 4.44 & 88.71 & Baik \\
\hline
\end{tabular}

Sumber: Pengolahan Data Primer, 2019

Berdasarkan kriteria konversi diketahui bahwa penilaian mahasiswa peserta Field Test tentang materi dan modul mata kuliah Statistika Pendidikan memperoleh rata-rata sebesar 4,44, sehingga berada pada kategori sangat layak. Selain itu, penilaian mahasiswa peserta Field Test tentang materi dan modul mata kuliah Statistika Pendidikan memperoleh Tingkat Capaian Responden (TCR) sebesar 88,71, sehingga berada pada kategori baik.

\section{Evaluasi (Evaluate)}

Pada tahap evaluasi ini, langkah-langkah yang peneliti lakukan adalah sebagai berikut:

Menganalisis penilaian ahli materi dan ahli media

Pada tahap ini, peneliti menganalisis penilaian dari ahli materi tentang materi pembelajaran yang disusun serta penilaian dari ahli media tentang media pembelajaran (modul) yang dikembangkan.

\section{Menganalisis penilaian mahasiswa}

Pada tahap ini, peneliti menganalisis penilaian mahasiswa tentang materi dan media pembelajaran (modul) yang dikembangkan.

\section{Produk akhir}

Setelah dilakukan proses validasi dan revisi, maka diperoleh produk akhir berupa modul mata kuliah Statistika Pendidikan.

\section{Kelayakan Modul Mata Kuliah Statistika Pendidikan Berdasarkan Penilaian Ahli Materi dan Ahli Media Ahli Materi}

Materi pembelajaran yang telah disusun divalidasi oleh 1 (satu) orang dosen pengampu mata kuliah Statistika Pendidikan di Fakultas Keguruan dan Ilmu Pendidikan Universitas Batanghari Jambi, yaitu Ibu Ayu Yarmayani, M.Pd. Validator memberikan penilaian terhadap materi pembelajaran yang peneliti susun dengan mengisi instrumen penilaian yang telah disediakan, yang terdiri dari 21 (dua puluh satu) item pernyataan. Adapun aspek yang dinilai oleh validator adalah aspek kelayakan isi dan aspek kelayakan penyajian. Penilaian validator ini tergambar tabel di bawah ini:

Tabel 10. Rekapitulasi Hasil Penilaian Ahli Materi

\begin{tabular}{clcc}
\hline No. & \multicolumn{1}{c}{ Aspek } & Rata-rata & Kategori \\
\hline 1. & Kelayakan Isi & 3,91 & Layak \\
2. & Kelayakan Penyajian & 4,1 & Layak \\
& Rata-rata Seluruh Aspek & $\mathbf{4 , 0 1}$ & Layak \\
\hline
\end{tabular}

Sumber: Pengolahan Data Primer, 2019

Setelah peneliti merevisi materi pembelajaran sesuai dengan komentar dan saran dari validator, maka peneliti menemui kembali validator guna menunjukkan hasil revisi yang peneliti susun. Selanjutnya, peneliti meminta validator untuk mengisi kembali instrumen penilaian yang disediakan. Penilaian validator setelah revisi tergambar pada tabel di bawah ini:

Tabel 11. Rekapitulasi Hasil Penilaian Ahli Materi Setelah Revisi

\begin{tabular}{|c|c|c|}
\hline Aspek & Rata-rata & Kategori \\
\hline 1. Kelayakan Isi & 4,55 & Sangat Layak \\
\hline 2. Kelayakan Penyajian & 4,5 & Sangat Layak \\
\hline Rata-rata Seluruh Aspek & 4,53 & Sangat Layak \\
\hline
\end{tabular}

Berdasarkan kriteria konversi diketahui bahwa (1) aspek kelayakan isi memperoleh rata-rata 4,55, sehingga berada pada kategori sangat layak, dan (2) aspek kelayakan penyajian memperoleh rata-rata 4,5 , sehingga berada pada kategori sangat layak. Dengan demikian, secara keseluruhan penilaian ahli materi setelah revisi berada pada kategori sangat layak.

\section{Ahli Media}

Media pembelajaran yang telah disusun divalidasi oleh 1 (satu) orang dosen Program Studi Pendidikan Bahasa dan Sastra Indonesia Fakultas Keguruan dan Ilmu Pendidikan Universitas Batanghari Jambi, yaitu Ibu Dr. Ade Rahima, M.Hum. Validator memberikan penilaian terhadap media pembelajaran yang peneliti 
susun dengan mengisi instrumen penilaian yang telah disediakan, yang terdiri dari 28 (dua puluh delapan) item pernyataan. Adapun aspek yang dinilai oleh validator adalah aspek kegrafikaan dan aspek bahasa. Penilaian validator ini tergambar pada tabel di bawah ini:

Tabel 12. Rekapitulasi Hasil Penilaian Ahli Media

\begin{tabular}{clcc}
\hline No. & \multicolumn{1}{c}{ Aspek } & Rata-rata & Kategori \\
\hline 1. & Kelayakan Kegrafikaan & 4,17 & Layak \\
2. & Kelayakan Bahasa & 4,00 & Layak \\
& Rata-rata Seluruh Aspek & $\mathbf{4 , 0 9}$ & Layak \\
\hline
\end{tabular}

Sumber: Pengolahan Data Primer, 2019

Setelah peneliti merevisi media pembelajaran sesuai dengan komentar dan saran dari validator, maka peneliti menemui kembali validator guna menunjukkan hasil revisi yang peneliti susun. Selanjutnya, peneliti meminta validator untuk mengisi kembali instrumen penilaian yang disediakan. Penilaian validator setelah revisi tergambar pada tabel di bawah ini:

Tabel 13. Rekapitulasi Hasil Penilaian Ahli Media Setelah Revisi

\begin{tabular}{cccc}
\hline No. & Aspek & Rata-rata & Kategori \\
\hline 1. & Kelayakan Kegrafikaan & 4,56 & Sangat Layak \\
2. & Kelayakan Bahasa & 4,5 & Sangat Layak \\
& Rata-rata Seluruh Aspek & $\mathbf{4 , 5 3}$ & Sangat Layak \\
\hline
\end{tabular}

Sumber: Pengolahan Data Primer, 2019

Berdasarkan kriteria konversi diketahui bahwa (1) aspek kegrafikaan memperoleh rata-rata 4,56, sehingga berada pada kategori sangat layak, dan (2) aspek kelayakan bahasa memperoleh rata-rata 4,5, sehingga berada pada kategori sangat layak. Dengan demikian, secara keseluruhan penilaian ahli media setelah revisi berada pada kategori sangat layak.

\section{Kelayakan Modul Mata Kuliah Statistika Pendidikan Berdasarkan Penilaian Mahasiswa}

Kelayakan modul berdasarkan penilaian mahasiswa peneliti peroleh dari hasil tahap Field Test yang telah peneliti laksanakan pada tanggal 04 Juli 2019 dengan subjek 15 (lima belas) orang mahasiswa Program Studi Pendidikan Ekonomi Fakultas Keguruan dan Ilmu Pendidikan Universitas Batanghari Jambi. Berdasarkan kriteria konversi diketahui bahwa penilaian mahasiswa peserta Field Test tentang materi dan modul mata kuliah Statistika Pendidikan memperoleh rata-rata 4,44, sehingga berada pada kategori sangat layak.

Nasution (2010:205) menjelaskan bahwa "Modul adalah suatu unit yang lengkap yang berdiri sendiri dan terdiri atas suatu rangkaian kegiatan belajar yang disusun untuk membantu peserta didik mencapai sejumlah tujuan yang dirumuskan secara khusus dan jelas". Modul merupakan salah satu bentuk bahan ajar yang dapat menciptakan proses pembelajaran lebih menarik. Hal ini senada dengan pendapat Hamdani (2011:220) yang mengemukakan bahwa salah satu manfaat modul bagi peserta didik adalah belajar menjadi lebih menarik karena dapat dipelajari di luar kelas dan di luar jam pembelajaran.

\section{SIMPULAN}

Berdasarkan pembahasan yang telah dikemukakan maka dapat diambil kesimpulan sebagai berikut:

1. Proses pengembangan modul mata kuliah Statistika Pendidikan merujuk pada model pengembangan ADDIE, yaitu:

a. Analisis (Analysis), yaitu analisis kebutuhan, analisis materi, dan analisis kompetensi.

b. Desain (Design), yaitu pengumpulan objek rancangan dan penyusunan instrumen penilaian.

c. Pengembangan (Develop), yaitu pembuatan media pembelajaran, validasi materi, revisi materi, validasi media, dan revisi media.

d. Implementasi (Implement), yaitu One to One, Small Group, dan Field Test.

e. Evaluasi (Evaluate), yaitu menganalisis penilaian ahli materi dan media, menganalisis penilaian mahasiswa, dan produk akhir.

2. Kelayakan modul mata kuliah Statistika Pendidikan berdasarkan penilaian ahli materi dan media, yaitu (a) Penilaian ahli materi sebelum revisi memperoleh rata-rata 4,01, sehingga berada pada kategori layak. Sedangkan, penilaian ahli materi setelah revisi memperoleh rata-rata 4,53, sehingga berada pada kategori sangat layak, dan (b) Penilaian ahli media sebelum revisi memperoleh rata-rata 4,09, sehingga berada pada kategori layak. Sedangkan, penilaian ahli media setelah revisi memperoleh rata-rata 4,53, sehingga berada pada kategori sangat layak.

3. Kelayakan modul mata kuliah Statistika Pendidikan berdasarkan penilaian mahasiswa, yaitu (a) One to One memperoleh rata-rata 4,49 dengan TCR 89, 78 sehingga berada pada kategori baik, (b) Small Group memperoleh rata-rata 4,16 dengan TCR 83,24 sehingga berada pada kategori baik, dan (c) Field Test memperoleh rata-rata 4,44 dengan TCR 88,71 sehingga berada pada kategori baik

\section{DAFTAR PUSTAKA}

Sugiyono. 2011. Metode Penelitian Kuantitatif, Kualitatif, dan $R \& D$. Bandung: Alfabeta.

Gafur, Abdul. 2012. Desain Pembelajaran: Konsep, Model, dan Aplikasinya dalam Perencanaan Pelaksanaan Pembelajaran. Yogyakarta: Ombak.

Nasution, S. 2010. Berbagai Pendekatan dalam Proses Belajar \& Mengajar. Jakarta: PT. Bumi Aksara.

Hamdani. 2011. Strategi Belajar Mengajar. Bandung: CV. Pustaka Setia. 